\title{
A Comparative Study of Clan Names and Clan Praises in Khumalo and Msogwaba Settlements
}

\author{
Jozi Joseph Thwala \\ M.E.R Mathivha Centre for African Languages, Arts and Culture, School of Human and \\ Social Sciences, Department of Siswati, University of Venda, Private Bag X 5050, \\ Thohoyandou, Limpopo Province, South Africa \\ Telephone: 015-9628298, Cell: 0731875298, E-mail: Jozi.Thwala@univen.ac.za
}

KEYWORDS Decorum. Descendants. Eulogy. Genealogies. Informants and Lineages

\begin{abstract}
The focus of the study is on the comparative analysis of clan names and clan praises in Khumalo and Msogwaba Settlements. A sample of twenty respondents or informants from each settlement was considered for interview in relation to their specific clan names and clan praises. Random sampling was used to obtain the information which represents the population of both settlements. A combination of qualitative and quantitative approaches was applied. The need for special collection, identification, classification, differentiation, description and interpretation seemed evident. These are the fundamental and key traditional aspects for historical, social and cultural life of every person. These are the global aspects that are not confined in folk poetry and folk sayings only, but they cut across all the literary and linguistic aspects. They are illustrious and notable reflections of the clan. They are rich in imagery and filled with historical and cultural narratives. Furthermore, they depict clan, sub clan, lineage and nation.
\end{abstract}

\section{INTRODUCTION}

The Swazi clan name is also called a surname. It has an extension termed clan praise. The use of clan names and clan praise covers all forms of social, cultural and national activities. The lines of clan praise are interchangeable and vary according to the spatial and temporal settings of the clan. It should be noted that the meaning, purpose and function of clan names and clan praises do not change. The Swazi themselves differentiate between sibongo (clan name) and sinanatelo (extension of the clan name). The two can be distinguished into the contrived genealogies. Clan names are general personal names irrespective of their origin, genealogy and derivation. In contrived genealogies only the names of selected ancestors are highlighted. These ancestral names are only those of individuals who are remembered by the nation for notable and remarkable contributions. They are the exemplary members to the families and as such, their deeds are expected to be emulated by their relatives and generations. They became social personalities who symbolize the nation's values. Ancestors who are non-achievers are deliberately excluded in contrived genealogies.
This is not a mere study of clan histories but it is deliberately confined to the clan name and clan praise as a special genre of Siswati oral poetry. It expresses the context of clan names and praises, as expressions of appreciation, benedictory formulae, acknowledgement, indebtedness and gratitude. The clan names and praises are looked at as speech acts that are clearly tied up within the ceremonial functions of the nation. They are part of poetic genre that is powerful words expressing feelings which in turn intuit relations between man and other facets of nature. In Swaziland and Mpumalanga Province, clan praises are heard in all fields of social discourse. Speech acts are imbued with significance: in carrying out such acts, cultural modes and prescriptions are observed. The recitation of clan praises is one approach a homestead used to acknowledge and validate the occupant's right and honour the founder of the clan. Furthermore, by reciting the praises of the family, one is seeking admission into a homestead and it is an official greeting that announces an amiable, kind-hearted and sociable visit.

Clan names and praises are identified and classified as oral literature and cultural aspects that are not qualitatively and quantitatively re- 
searched by scholars. They are collected by various scholars, but no distinctive attention is being given to them. They need a specific collection, categorization, identification, description, interpretation and differentiation. Emaswati clan names and praises have long been the neglected aspects of southern African oral poetry. Instead, the praises of kings and chiefs are aspects which have occupied the pursuits and interests of most scholars during the past century.

Clan names and praises cannot be neglected in entire society because they are the roots and norms of the nation. They are rich in imagery and filled with historical descriptive and narratives. They serve various social functions and play a significant role in important cultural ceremonies. It is indeed high time that the clan names and praises receive the scholarly attention they deserve and it is hoped that clan names and praises will both attract the notice of researchers in oral poetry and be a forerunner for further research works. However, their functions are not highlighted and acknowledged; therefore, they need to be researched from the King, Queen mother, councils, clans and lineages. The relationship of clan names, praises, songs and other folkloric aspects needs to be outlined and adequately explained.

Kamera (2001:11) defined clan names and praises as follows:

The Swazi clan name is clearly distinguished into sibongo (core clan name) and sinanatelo (clan praises) from nanatela (add, extend). Clan praises are often an extension or development of the meaning of sibongo and are separable into contrived genealogies and actual praises. Contrived genealogies include names of founders of clan lineages and other selected eminent clan ancestors. The actual praises are a collection of experts from the praises or boasts of ancestors in the contrived genealogies.

The objectives of this paper are to identify and compare the clan names and praises that are found in Khumalo settlement, under Khumalo's chieftaincy and Msongwaba settlement, under Dlamini's chieftaincy. The second objective was to outline and explain the similarities and differences as well as the significance of clan names and praises within the selected settlements.

Finnegan (1990:111) postulated that praise names serve as a source of formal praise poetry and are bestowed to people to give a full description of clans. They are justifiably and right- fully special type of African panegyrics. Swazi clan or family praises are in fact heroic recitations or poetic boasts. They are eulogistic and celebrative reflections that accompany the family surname as a constant element of this poetic genre. The clan name identifies the family and clan cluster as a social organization constitute the clan's anthem and verbal emblem. They are short sentence commemorative of notable and significant actions and events. They validate the mythologies of roots, beliefs, cultural practices and social standing of the clan. They are verbal acts, that interlude and prelude negotiations of cultural significance.

Clan praises as a genre of oral poetry provide a good example of stylised content and subject. The content and style of presentation are particular to the genre and culture. The content bears the stamp of the clan as a common presentational decorum. In this genre, aesthetics and folklore are brought together; values and norms are asserted and upheld. Politeness and propriety are cultural landmarks of this genre that are played out within a context of honour, decency and integrity.

\section{A Historical Background of the Specific Chieftaincies: Khumalo and Dlamini}

\section{Khumalo Chieftaincy}

Mthayiza, the son of Myakayaka Khumalo, was originally from Ngome area in Kwazulu-Natal. He was given charge of an area in the Northern Lowveld by King Mswati II. After the death of his sister, Sisile, the mother of Ludvonga II, he fled north across the Sabie River with 2000 followers and a fully-trained regiment. Ultimately, he settled with his people between Nkomazi (Komati) and Mgwenya (Crocodile) Rivers. Mthayiza, an army commander and hero clashed with King Mbandzeni and decided to vacate his homestead near Ngugwane stream.

The Khumalo clan settled at Gutjwa, Gutjwa Kop, Embonisweni, Emvangatini,Emahukube, Emanyeveni, Ephameni, Emgcobaneni, Eshweni, Khumbula, Ngodvwana, Halfway and other places. The Khumalo genealogy is as follows: Mthayiza, Sibhulo, Makhahlela, Njojo, Mgiyeni and Sibusiso (Van der Merwe 1992).

History shows that one of the sons of King Mswati II of Swaziland, Shishila (from a minor hut), left Swaziland and settled near the Croco- 
dile River at the present Alkmaar. He bore Msogwaba, who was removed from the area to a farm which was owned by a certain Pienaar family. The settlement is named after its chief Msogwaba. His son, Gedlembane followed his father to the throne. The clan is currently led by chief Maminza.

\section{RESEARCH METHODOLOGY}

Research methodology refers to the steps, plan, schemes and strategies for collecting and analysing the data (Polit and Beck 2008: 723). This part discusses the study setting, procedures population and sample selection. It focuses on the methods of research adopted, how and where data will be gathered and analysed. It is the study that is classified as oral literature or tradition and folk poetry. Oral literature can be compared with written literature as Wilson (1998: 27) asserted:

Comparative literature may mean the study of oral literature. The study of oral literature is an integral part of literary scholarships, for it cannot be divorced from the study of written work and there is a continuous interaction between oral and written literature.

As asserted by the scholar, comparison is based on oral and written literature. Jost (1974: 36) expressed his view on the matter more succinctly as follows:

A comparative study does not have to be comparative on every page, nor even in every chapter ... The essaying of intent, emphasises and execution require both objective and subjective judgement.

The aspects of comparative literature discussed above are not to be regarded as exhaustive but only as indication of some of the existing aspects of comparison in the study of oral tradition. It is evident to note that the study compares clan names and praises in the specific geographical settlements.

The objectives of the study are answered by the research questions. It employed both qualitative and quantitative research approaches. Qualitative methods were used to collect data through key informant interviews, structured and semi-structured interviews (Babbie 2010). Quantitative methods were used to collect and analyse the quantifiable data obtained through individual structured and unstructured questionnaires. The two approaches are chosen for the purpose of complementing each other. Thus, the study focuses on primary data collected through qualitative and quantitative methods.

\section{RESULTS}

The total number of respondents who were respectively interviewed in Gutjwa and Msogwaba settlements was 20 . The results reflect the distribution of clan names as follows:

It is evident that in Table 1 of Khumalo settlement the dominating clan name is Khumalo, while in Table 2 of Msogwaba settlement is Dlamini. These clan names reflect the ruling chieftaincies in their respective areas. The actual results from the respondents show that for the Khumalo chieftaincy settlement, the following are the respective figures: Khumalo 6/20 (15\%), Dlamini 3/20 (15\%), Lukhele 3/20 (15\%), Ndlovu 2/20 (10\%), Motsa 2/20 (10\%), Mdluli 2/20 (10\%), and Ngwenya 2/20 (10\%). For the Dlamini settlement the figures are as follows: Khumalo 6/20 (30\%), Maseko 4/20 (20\%), Nxumalo 3/20 (15\%), Nhleko 2/20 (10\%), Nkhambule 2/20 (10\%), Mvubu 2/20 (10\%) and Nyoni 1/20 (5\%).

Table 1: Khumalo

Catetory 1:

\begin{tabular}{lcc}
\hline Clan names & Respondents & Percentages \\
\hline Khumalo & $6 / 20$ & 30 \\
Dlamini & $3 / 20$ & 15 \\
Lukhele & $3 / 20$ & 15 \\
Ndlovu & $2 / 20$ & 10 \\
Motsa & $2 / 20$ & 10 \\
Mdluli & $2 / 20$ & 10 \\
Ngwenya & $2 / 20$ & 10 \\
& 20 & 100 \\
\hline
\end{tabular}

Table 2: Msogwaba

Catetory 1:

\begin{tabular}{lcc}
\hline Clan names & Respondents & Percentage \\
\hline Dlamini & $6 / 20$ & 30 \\
Maseko & $4 / 20$ & 20 \\
Nxumalo & $3 / 20$ & 15 \\
Nhleko & $2 / 20$ & 10 \\
Nkhambule & $2 / 20$ & 10 \\
Mvubu & $2 / 20$ & 10 \\
Nyoni & $1 / 20$ & 5 \\
& 20 & 100 \\
\hline
\end{tabular}

An analysis of the results shows the clan names that are commonly found in the two chieftaincies settlements. In the Khumalo chieftaincy, the Khumalo surname dominates in the area, 
followed by the Dlamini and the Lukhele of Emvangatini, a place that is named after species of forest trees called pterocarpus angolensis. In Msogwaba, the Dlamini dominates the area, followed by Maseko and Nxumalo.

It should be noted that the Dlamini clan name is also found in the Khumalo settlement due to the proximity of the areas. Five Khumalo respondents revealed that they belong to Mthayiza, while one mentioned that he belongs to Mgangeni, a brother to Queen Sisile. All three Lukhele informants mentioned Siligane, one of the outstanding heroes of Emaswati. The two Dlamini's respondents asserted that they were descendants of Somcuba and Mbilini respectively. The two Mdluli respondents reported that they were descendants of Bhekiswako and Sikhandzisa. It should also be noted that the three Nxumalo respondents claimed to be descendants of Mawewe, while one claimed to be descendant of Mzila.

The results show that each settlement is composed of various clan names that pay allegiance to respective chieftaincies. It was further noted from the respondents that the following clan names: Nxumalo, Mdluli and Lukhele show a historical and social reference of other nearby chieftaincies.

\section{DISCUSSION}

Mthethwa (2014: 120) advocated the following views about clan praises:

Tinanarelo ngumlandvo wemabito alabadzala. Umlandvo wetinanatelo sewufana nematekelo. Tinanatelo tikhombisa buntfu nebuve bemuntfu.

(Clan praises are the history of forefathers' names. The history of the clan praises are similar to legendary tales. Clan praises depict humanness and tribal category of a person)

Clan praises are fundamental concepts in the life of every African. The highlights of each clan name are as follows: The Khumalo informants extolled the praises as follows:

$\begin{array}{ll}\text { Khumalo! } & \text { (Khumalo! } \\ \text { Mntungwa, } & \text { Mntungwa, } \\ \text { Mbulazi, } & \text { Mbulazi, Ndlangamandla, } \\ & \text { Ndlangamandla, Kuhlase, } \\ & \text { Kuhlase, } \\ \text { Wena wadla umuntfu } & \text { Who ate someone by } \\ \text { umyenga ngendzaba, } & \text { deceiving him, } \\ \text { Maphosa uphosile, } & \text { When you fight you do not } \\ & \text { retreat, } \\ \text { Uphosa sikhali } & \text { You fight with Jokova's }\end{array}$

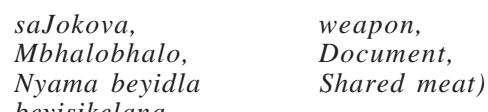

The ethnic background and history are referred to Mthayiza, who led the clan to the area between Inkomazi and Mgwenya rivers. They provided information about a hero, Mgangeni, Queen Sisile's father, who led another Khumalo group. The other Khumalo group built its homestead near Dlomodlomo hills at Manzana, led by Magadlela, who bore Queen Nandzi, also known as LaMagadlela. The other group was led by Mzilikazi, the son of Mashobane, which moved northwards and ended-up forming a new indigenous nation called the Northern Ndebele. They are also descendants of Khumalo clan and Mntungwa. The historical, temporal, social and genealogical development in their clan praises reflect possessiveness in the following lines: Wena waMzilikazi! (You of Mzilikazi clan!) Wena waMgangeni! (You of Mgangeni clan!) Wena waMagadlela! (You of Magadlela clan!). All the above-mentioned figures are Khumalo's outstanding heroes, commanders and strategists who played a crucial role in the development of the Nguni nations.

The Lukhele's informants gallantly highlighted the following:

$\begin{array}{ll}\text { Lukhele! } & \begin{array}{l}\text { (Lukhele! (from khelela, to } \\ \text { draw water) } \\ \text { Mdluli, }\end{array} \\ \text { Mhlanti } & \text { One who cleans the main } \\ \text { wendlunkhulu, } & \text { homestead, } \\ & \text { NaboNkhosi, } \\ & \text { Mother of the king, } \\ \text { NaboMavovo } & \text { Mother of Mavovo } \\ \text { NaboNoyoni isindwa } & \text { Mother of the bird whose tail } \\ \text { sisila kusuka. } & \text { is too heavy for the bird to } \\ & \text { take off) }\end{array}$

The clan name reflects their role of occupation in the Dlamini royal family of carrying traditional medicines. Motherhood is reflected in the clan's praise when it is extolled: Nabonkhosi (Mother of king), naboMavovo (Mother of Movovo) and NaboNyoni (Mother of Nyoni). The clan names Lukhele and Mdluli depict a relationship lineage and they are from one descendent. The clan name, Lukhele derives from the name of their ancestor, which was bestowed maybe from the ideophone, khele (to limp), umkhele (the large timber tree, also called white stinkwood) or khelela (to draw water).

The Ndlovu informants highlighted the following about their clan: 


$\begin{array}{ll}\text { Ndlovu! } & \text { (Ndlovu (elephant)! } \\ \text { Gatjeni, } & \text { Gatjeni, } \\ \text { Boya benyatsi, } & \text { Fur of the buffalo, } \\ \text { Busongwa } & \text { It curls and rearrange } \\ \text { busombuluka, } & \text { itself, } \\ \text { Nkhomo tidla ekhaya Cattle that eat at home } \\ \text { Ngokweswela } & \text { Due to lack of shepherd) } \\ & \text { belusi. }\end{array}$

The clan name is about a big wild animal known for its viciousness and physical built. Its lineage reflects Gatjeni. The totems of the clan are elephants, buffalo and cattle.

Motsa, Madlebenkhomo (ears of a cow), Mvulane (of the rain). It should be noted that the Motsa also make use of the reference, wena loluhlata njengencoshane (you who are green like cypenus) like Gwebu, Shabangu and Mnisi. According to the respondents the Motsa and Mnisi are one family: Mnisi controls the rain, thus helping people during drought. Mnisi would magically manipulate his charms, which were known only to himself. Thus refers to Mvulane (of rain). The Motsa clan are said to have big and sharp ears. They can hear distant sounds. They do not eat a cow's ears as it is part of their clan praise. They eat all the other meats but leave the ears to be eaten by others, meaning those who are not Motsas.

$\begin{array}{ll}\text { Motsa! } & \text { Motsa! (from otsa to bask; re- } \\ & \text { port or inform against) } \\ \text { Mvulane } & \text { Of the rain, } \\ \text { Ndlebenkhomo } & \text { Ear of a cow } \\ \text { Wena longayidli } & \text { You who do not eat the ear of a } \\ \text { indlebe } & \text { cow } \\ \text { Jojo loluhlata } & \text { Jojo who is as dark as the } \\ \text { lonjengencoshana } & \text { cyperus }\end{array}$

The Mdluli's respondents recited and further gave the briefs of the clan as follows:

\begin{tabular}{|c|c|}
\hline Mdluli! & $\begin{array}{l}\text { (Mdluli (pass by, excel, surpuss, } \\
\text { exceed) }\end{array}$ \\
\hline Bhekiswako, & Bhekiswako, \\
\hline Sukuta, & Sukuta, \\
\hline $\begin{array}{l}\text { Wena wabhekis' } \\
\text { inkhos'elusaseni }\end{array}$ & $\begin{array}{l}\text { You who guided the king to a } \\
\text { sacred room, }\end{array}$ \\
\hline Luvuno, & Luvuno, \\
\hline $\begin{array}{l}\text { Luvuno } \\
\text { alunamahloni, }\end{array}$ & Luvuno knows no shame, \\
\hline BakaMdluli & The Mdluli do not eat \\
\hline $\begin{array}{l}\text { abayidli } \\
\text { inyama yembuti, }\end{array}$ & goat meat, \\
\hline badla ye & They eat \\
\hline
\end{tabular}

There are two sub-clans of the Mdluli clan; the Mdluli Sikhandzisa, from which comes the king's right hand man insila, and the Mdluli Bhekiswako from which came the Queen Labotsi- beni, mother of Mahlokohla, father of Sobhuza II. The Mdluli clan was incorporated by the Dlamini early in their migration from Tembe territory. The Mdluli had settled in an area known as kaMbikiza (place of Mbikiza) and had their own powerful chieftaincy. Dlamini III desired the peaceful and organized manner in which this group conducted its affairs and persuaded them to join him. He assigned them the task of assisting in the indlunkhulu (great hut). The name Mdluli means "go ahead" and comes from dlula (pass, go ahead) and was given the leader and founder of the clan.

Ngwenya's respondents recited their clan as follows:

$\begin{array}{ll}\text { Ngwenya! } & \text { Ngwenya! (Crocodile) } \\ \text { Mntimandze, } & \text { Mntimandze, } \\ \text { Mabuya, } & \text { The returner, } \\ \text { Lubhambolunye, } & \text { Single-ribbed, } \\ \text { Tingaba timbili } & \text { If there are two } \\ \text { Tabuya nenina } & \text { They came from the mother, } \\ \text { Ekhabonina, } & \text { From her home place } \\ \text { Ngwenya! } & \text { Crocodile!) }\end{array}$

The crocodile is a sacred animal of the Ngwenya clan. The Ngwenya hails between Mkhondvo and Ngwempisi Rivers. It is a united clan which follows its cultures and traditional practices.

All Dlamini respondents gave their clan praises and a brief history as follows:

$\begin{array}{ll}\text { Dlamini! } & \text { (Dlamini! (Eater at noon) } \\ \text { Mlangeni! } & \text { You of the Sun! } \\ \text { Wena wekunene } & \text { You of the right hand } \\ \text { Wen'umuhle } & \text { You the most beautiful } \\ \text { kakhulu } & \\ \text { Wena weluhlanga } & \text { You of the original stock of } \\ \text { lwakaNgwane } & \text { Ngwane } \\ \text { Wena wacedza } & \text { You who scourged the } \\ \text { Lubombo } & \text { Lubombo } \\ \text { ngekuhlehletela } & \text { range in your flight.) }\end{array}$

The Swazi king comes from lineages of the Nkosi Dlamini clan, founded by Dlamini I, a man of Embo-Nguni stock. He migrated from central Africa around the late fifteenth century to SouthEastern Africa with other groups of people and settled on the Mozambian coast. The Dlamini are praised as Mlangeni (You of the Sun). The metaphorical use of the sun refers to the source and derivation of the name Dlamini. The founding ancestor of the clan ate at noon, thereby breaking a long observed taboo and whereupon his younger brother who was watching, ex- 
claimed, “Hawu, udl' emini!”(You eat at noon!). He then became an acclaimed hero and has mystical powers. He was subsequently named Dlamini (One who eats at noon).

The Maseko respondents praised their clan and founder highlights their brief history as follows:

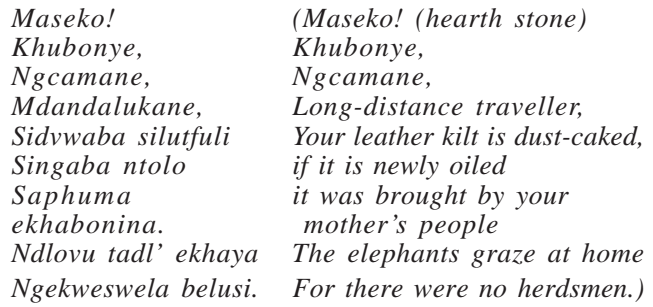

The Maseko are among the earlist inhabitants of Swaziland and their clan name states that they are of Ntungwa origin, Mntungwa, the chosen one. They became the chosen ones when Ndvungunye (1790-1815) married the daughter of the famous Luhleko Maseko. It is not clear as to when and where the Maseko broke off from the main Ntungwa group during migration from Central Africa, but they are said to have travelled long distances, Mdandalukane (long distance traveller). Their leather kilts collected dust from the long journey, "Your leather kilt is dust-caked."

When Sobhuza I (1815-1836) moved from the south to central Swaziland, he found the Maseko, who were the most formidable power. Still militarily weak, Sobhuza I dared not antagonize the Maseko and instead, married princess Lambombotsi of Mgazi, chief of the Maseko. The diplomatic marriage did not lead to the fruitful results. Lambombotsi was not chosen as main wife to bear the heir. The Maseko are among those who held superior position in the whole nation because of their professional skills of making spears, knives, axes and hoes using hearth stone.

The Nxumalo respondents extolled their praises as follows:

$\begin{array}{ll}\text { Nxumalo! } & \text { (Nxumalo (Baby's sucking } \\ & \text { bottle made of skin) } \\ \text { Mkhatjwa, } & \text { Mkhatjwa, } \\ \text { Ndwandwe, } & \text { Ndwandwe, } \\ \text { Wena waseGudu, } & \text { You of Gudu, } \\ \text { Wena waseBuhleni } & \text {,You of Buhleni, } \\ \text { Wena wase } & \text { You of Gudunkhomo, } \\ \text { Gudunkhomo } & \\ \text { Nkabanhle } & \text { Beautful navel - the two }\end{array}$

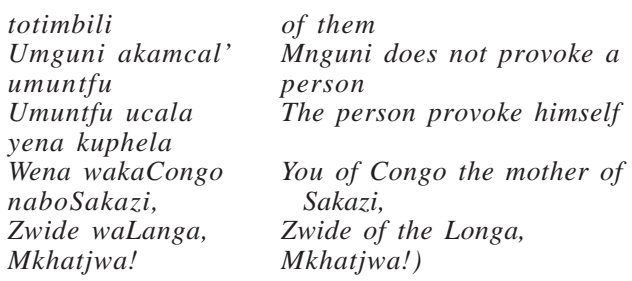

The name Mkhatjwa is added thus, Mkhatjwa lokhatjwa ngetinyawo letindze naletimfishane (Mkhatjwa who is kicked by long and short feet). This is used to praise any Nxumalo person. The informant said Gudunkhomo is a place around Phongolo, which is largely inhabited by the Nxumalo. The proper name is derived from the infinitive verb kuguda 'to milk a cow before the calf sucks'. In this place there are two mountains:

Gudunkhomo Ntsaba Gundukhomo Ntsaba lenkhulencane (Small lu (Big Mountain

Mountain Gudunkhomo) Gudunkhomo)

The big mountain is called, Gudunkhomo lomkhulu. The small mountain is called $\mathrm{Gu}$ dunkhomo lomcane. There is a royal home of the Nxumalos at Gudunkhomo lomkhulu.

The two Nhleko respondents furnished the same clan praise and historical background as follows:

$\begin{array}{ll}\text { Nhleko! } & \text { (Nhleko! } \\ \text { Mgilija, } & \text { Mgilija, } \\ \text { Mngcangu lomhlophe } & \text { Mngangu who are white } \\ \text { Netinyawo takhe } & \text { together with his feet } \\ \text { Bacophe tandla } & \text { They cleaned thier hands but } \\ \text { bashiye tinyawo } & \text { not the feet, } \\ \text { Mabheng'amahle } & \text { Mabhengu who is beautiful, } \\ \text { kakhulu } & \\ \text { Thusha letincane } & \text { Small Thusha who beat a } \\ \text { letabhinc'indvodza } & \text { man } \\ \text { Wena lohamb'eceleni } & \text { You who walk and cannot be } \\ \text { ungakhutjwa lula } & \text { tripped by a stone, } \\ \text { Wena wakaLaHula. } & \text { You of LaHula.) }\end{array}$

The clan initially settled at Logoba between Mozambique and Swaziland. They were led by the first two leaders of the clan, Nhleko and Mgilija. They were later forced out of the area by political coercion from the people who had established the Gaza Empire, the Shangaans. They then moved southwards and finally settled at Lubulini area in the Lubombo district. They found refuge under the Mngometulu clan. Mgilija's son, Mngcangu had a bright complexion, thus he was praised as having white feet. 
Mabhengu, one of the sons of Mgilija, was a herbalist, thus he was praised as Nyangandvuna (male herbalist). He planned to break away from his clan because he did not want to be under the Mngometulu clan. He wanted to retain his clan and become their hero and leader, but unfortunately he died before he could accomplish his wishes.

It is alleged that the Nkhambule are Sothos by origin. They arrived in the country rolling in the silulu (grain basket). They are one of the clans that were already there when the Swazis arrived. The Nkhambule are 'king bearers'. They are usually buried in the afternoon, thus 'follower of the sun'. The Nkhambule, unlike others, are buried at sunset, for their spirit to follow the sun. The Nkhambule respondents extolled as follows:

$\begin{array}{ll}\text { Nkhambule! } & \begin{array}{l}\text { (Nkhambule! } \\ \text { Msutfu } \\ \text { Msutfu,(The Sotho) }\end{array} \\ \text { Msutfu Mswati, } & \text { Msutfu Mswati (The Sotho Swati) } \\ \text { Mtilankhatsa, } & \begin{array}{l}\text { Abstainer of ring-like knitted } \\ \text { grass }\end{array} \\ \text { Mlandzelalanga } & \text { Follower of the sun } \\ \text { Leliyoshona } & \begin{array}{l}\text { On its way to set at Encuteni } \\ \text { Encuteni }\end{array} \\ & \text { Gasolo! } \\ & \text { Gasolo!) }\end{array}$

The Mvubu informants recited their praise names as follows:

$\begin{array}{ll}\text { Mvubu! } & \text { Mvubu! (Hippopotamus!) } \\ \text { Matfunywa, } & \text { The Delegate, } \\ \text { Imvubu abayidli } & \text { A hippo is not eaten by those } \\ \text { abashaywa ngiyo, } & \text { who are struck by it, } \\ \text { Mvubu, } & \text { The Hippopotamus, } \\ \text { Geza, } & \text { Wash, } \\ \text { Tfobhoyi! } & \text { Tfobhoyi!) }\end{array}$

The clan name Mvubu, is named after a hippopotamus. It is a clan found in the Northern of
KwaZulu Natal, Mpumalanga Province, in the southern part of Limpopo Province, Swaziland and Western Mozambique.

It is alleged that Nyoni (the bird) was the name given to the founder of the clan. He came across a bright red-feathered bird and took it to the king. The king gratefully thanked and named him Nyoni. The king then decreed that the feathers of this bird should not be seen to be used by anyone else but on special royal occasions by members of the royal family. Whenever one puts on the Swazi traditional attire, one also puts these special feathers on his head, but only if he is of royalty. The bird ligwalagwala or loury's scientific name is turacus corythaix.

The Nyoni respondents gave the same submissions:

$\begin{array}{ll}\text { Nyoni } & \text { Nyoni (The bird) } \\ \text { Gwalagwala } & \text { Gwalagwala (the loury) } \\ \text { Nyoni yemakhosi } & \text { Bird of the ceremony } \\ \text { Awuhlonywa } & \text { You are not inserted by } \\ \text { ngebafokati } & \text { commoners } \\ \text { Uhlonywa } & \text { You are inserted by kings } \\ \text { ngemakhosi } & \\ \text { Gwalagwala! } & \text { Loury! }\end{array}$

\section{Categorisation of Clan Names and Clan Praises}

The sampled clan names and praises found in both chieftaincies are categorised as follows:

Section one : Clan name, ancestor's name, core clan name, surname or personal name.

Section two : Primary or praise name.

Section three : Secondary praise name or names.

Section four : Praise phrase or phrasal praise name and extensions.

Table 3: Khumalo chieftaincy

\begin{tabular}{|c|c|c|c|c|c|c|c|}
\hline $\begin{array}{l}\text { Clan namel } \\
\text { Ancestor's } \\
\text { name } \\
\text { Personal name }\end{array}$ & Khumalo & Dlamini & Lukhele & Ndlovu & Motsa & Mdluli & Ngwenya \\
\hline $\begin{array}{l}\text { Primary/main } \\
\text { praise name }\end{array}$ & Mntungwa & Nkhosi & Mdluli & Gatjeni & Mvulane & Bhekiswako & Mntimandze \\
\hline $\begin{array}{l}\text { Secondary } \\
\text { praise name }\end{array}$ & $\begin{array}{l}\text { Mbulazi } \\
\text { Ndlangamandla }\end{array}$ & $\begin{array}{l}\text { Mlangeni } \\
\text { Hlubi } \\
\text { Ludvonga }\end{array}$ & $\begin{array}{l}\text { Mhlanti } \\
\text { benyatsi }\end{array}$ & $\begin{array}{l}\text { Boya } \\
\text { benkhomo }\end{array}$ & Madle & Sukuta & Mabuya \\
\hline $\begin{array}{l}\text { Praise phrase/ } \\
\text { Phrasal praise } \\
\text { name }\end{array}$ & $\begin{array}{l}\text { Wena } \\
\text { wadla } \\
\text { umuntfu umyen } \\
\text { ga ngendzaba }\end{array}$ & $\begin{array}{l}\text { Sidlu } \\
\text { buladledle } \\
\text { saka } \\
\text { Lobamba }\end{array}$ & $\begin{array}{l}\text { Mhlanti } \\
\text { wend } \\
\text { lunkhulu }\end{array}$ & $\begin{array}{l}\text { Buyaso } \\
\text { ngwa } \\
\text { busom } \\
\text { buluka }\end{array}$ & $\begin{array}{l}\text { Umfula } \\
\text { lowelwa } \\
\text { tin- } \\
\text { khonjane }\end{array}$ & $\begin{array}{l}\text { Wena } \\
\text { wabhekis’ } \\
\text { inkhosi } \\
\text { elusaseni }\end{array}$ & Bhambolunye \\
\hline
\end{tabular}




\section{Clan Praise in a Sequence Form}

\section{Rhythm in Clan Names}

What is further noted in the randomly-selected clan names are their rhythmic formations. In Gutjwa (Table 3), the following four clan names are made up of three syllables each: Khumalo, Dlamini, Lukhele and Mdluli (with the latent vowel u), while the Msogwaba (Table 4) are Dlamini, Maseko, Nxumalo and Nkhambule. The last three clan names from first category: Ndlovu, Ngwenya and Motsa are formed by two syllables. A similar formation is noted from second category comprises the following clan names: Nyoni (bird), Mvubu (hippopotamus) and Nhleko (laughter).

Rhythm is defined by Nyembezi (1974:23) as follows:

The metrical effect which is produced in verse, prose, music or motion by the relations in quantity, stress, time or energy between the syllables, words, notes, or movements that succeed each other.

In the present study, however, the researcher deals with rhythm in clan names and clan praises. On the other hand in poetry, for example, the metrical balance is a deliberate effort on the part of the poet; here the researcher is dealing with spontaneous development.

\section{The Use of Clan Names and Praises}

Clan praises have a number of functions in society, including the establishment of uniqueness, distinctiveness, gratitude, appreciation and applauding.

\section{- Clan Praises Establish Identity}

In fact, they go further than simply establishing clan identity; they may be used to establish related clan identity. Many clans are subclans of some original 'founder' clan and will share many clan praises.

\section{- Praises are Used as Address Forms}

Clan praises are frequently used as address forms, particularly for males. Men greeting each other in casual circumstances, such as at work or on the road, for example, will commonly use the clan praise. The clan is the extension of kinship and when two Swazi meet for the first time they frequently as, "What is your sibongo (clan praise name)?”

\section{- Praises are Used to Thank, Flatter and Congratulate}

When thanking someone for a gift or a favour, clan praises are used. As Mzolo (1978: 212) contended the following: if ... a service [is rendered] which merits appreciation, it is not enough simply to say Ngiyabonga, "I thank you'. The one who expresses thanks goes further and recites some, if not all, the clan praises.

\section{- Clan Names may be Used to Encourage}

You encourage a person to pursue any duty or function using praises. The use of his clan name encourages him or her to do the work that is praiseworthy and saluted by many.

\section{- Praises are Used in Various Rite and Ceremonies}

In addition to the ordinary situations, clan praises are an important feature of ceremonial occasion. A full recitation of the clan praises is evident to all national events and ceremonies.

\section{CONCLUSION}

In conclusion, it is noted that no verbal and written arguments that can be completed on clan names without referring to clan praises. Clan names are an inseparable package that reflects lineage, sub-clan and relationship. A clan name is also called an ancestral or personal name, which is shared by related groups, indicating a point where these separated and at the same time a point where they merge. On the basis of such kinship relationship, as a cultural practice and norm, intermarriage is prohibited. In the sampled number of clan names from the two settlements, there are few other clan names that were mentioned by the informants. The categorisation of clan names is according to various aspects namely; animals: Mvubu (hippopotamus), Ndlovu (elephant) and Ngwenya (crocodile). Birds: Nyoni (bird), Nhlengetfwa (dolphin) and 
Mvemve (African pied wagtail). Actions of notable individuals are also used; for example: Tfwala (carry), Tsela (pour) and Khwela (climb up). Botanical relationship: Hlongwa (type of long grass used for thatching), Khumalo (species of thorny treess, scientifically cassinopsis sapensis) and Ngobese (species of bogwood plant) were also mentioned. Character: Vilane (lazy one), Vilakazi (very lazy one) and Sukati (strategist) were reported. The dominant language in both settlements is Siswati. The cultural practice of Swazi nation is followed to the latter. Although, there are dialectical inclinations to their linguistics competences due to Simbayi and Sipulane of the eastern Sotho clans that are found in the area, their significance is noted for the development of the language.

\section{RECOMMENDATIONS}

It is strongly recommended that clan names and clan praises be critically analysed to depict the differences and similarities. The history of clan names and clan praises can bring more light about each genre's background, meaning and significance. The relationship of clan names and clan praises needs further exploration from clan name, main or primary praise name, first, second or third secondary praises name to the phrasal praise name extensions. Clan name and clan praise should reflect the cultural and social practices of the nation in a broader way.

\section{NOTE}

Siligane Lukhele, was a military hero of Emaswati nation, who was deployed to take charge of Emphakeni area. Somcuba Dlamini, was a son of Sobhuza I (Somhlolo), who fled from the royal homestead, but ultimately killed. Mbilini Dlamini, was the eldest son of Mswati II who fled to king Cetshwayo in KwaZulu Natal. Mawewe Nxumalo, was a younger brother of Mzila and son of Soshangane. Mzila Nxumalo, was the eldest son of Soshangane, who played a major role in building the Gaza Empire.

\section{REFERENCES}

Babbie E 2010. The Basic Social Research. New York: Thomson Wadsworth.

Finnegan R 1990. Oral Literature in Africa. Oxford: Clarendon Press.

Jost F 1974. Introduction to Comparative Literature. New York: Bobbs-Merrill Publishers.

Kamera WD 2001. Swazi Family Praises. Mbabane: Websters Publishers.

Mthethwa NC 2014. Silulu SeMaswati. Randhart: Lectio Publishers.

Mzolo DM 1978. Zulu Clan Praises. Social System and Tradition in Southern Africa Eds. Cape Town: Argyle J. \& Perston-Whyte E. Oxford University Press.

Nyembezi CJS 1974. Zulu Proverbs. Johannesburg: Wits.

Polit ED, Beck TC 2008. Research in Nursing and Health: Inter-sectionalising European Politics, Bridging Gender \& Ethnicity. Philadelphia: Routledge Publishers.

Van der Merwe PDR 1992. Ethnology Unpublished Document: Khumalo Chieftaincy. Pretoria.

Wilson JB 1998. English Literature: A Survey to Students. London: Longman Publishers.

Paper received for publication on September 2015

Paper accepted for publication on December 2016 